\title{
EU Legal Framework for Safeguarding Air Passenger Rights
}


Francesco Rossi Dal Pozzo

EU Legal Framework for Safeguarding Air Passenger Rights

包 Springer 
Francesco Rossi Dal Pozzo

Dipartimento di Diritto pubblico italiano

e sovranazionale - Department of Italian

and Supranational Public Law

Università degli Studi di Milano - University

of Milan

Milan

Italy

ISBN 978-3-319-08089-5

ISBN 978-3-319-08090-1 (eBook)

DOI 10.1007/978-3-319-08090-1

Springer Cham Heidelberg New York Dordrecht London

Library of Congress Control Number: 2014942685

(C) Springer International Publishing Switzerland 2015

This work is subject to copyright. All rights are reserved by the Publisher, whether the whole or part of the material is concerned, specifically the rights of translation, reprinting, reuse of illustrations, recitation, broadcasting, reproduction on microfilms or in any other physical way, and transmission or information storage and retrieval, electronic adaptation, computer software, or by similar or dissimilar methodology now known or hereafter developed. Exempted from this legal reservation are brief excerpts in connection with reviews or scholarly analysis or material supplied specifically for the purpose of being entered and executed on a computer system, for exclusive use by the purchaser of the work. Duplication of this publication or parts thereof is permitted only under the provisions of the Copyright Law of the Publisher's location, in its current version, and permission for use must always be obtained from Springer. Permissions for use may be obtained through RightsLink at the Copyright Clearance Center. Violations are liable to prosecution under the respective Copyright Law.

The use of general descriptive names, registered names, trademarks, service marks, etc. in this publication does not imply, even in the absence of a specific statement, that such names are exempt from the relevant protective laws and regulations and therefore free for general use.

While the advice and information in this book are believed to be true and accurate at the date of publication, neither the authors nor the editors nor the publisher can accept any legal responsibility for any errors or omissions that may be made. The publisher makes no warranty, express or implied, with respect to the material contained herein.

Printed on acid-free paper

Springer is part of Springer Science+Business Media (www.springer.com) 
To my parents 


\section{Contents}

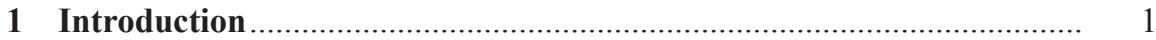

2 Aviation Safety ...................................................................................... 7

2.1 Origin of and Difference Between Aviation Safety and Aviation Security .................................................................... 7

2.2 Aviation Safety in International Law ............................................... 11

2.3 The History of Aviation Safety in the European Union ................... 13 2.3.1 Aviation Safety Regulation in the European Union .............. 14

2.4 Directive 2004/36/EC and the Enquiry into the 'SAFA Programme' .............................................................................. 24

2.5 Regulation (EC) No 2111/2005 and the Right of Passengers to Know the Identity of Operating Air Carriers ............. 32

2.6 'Accident and Incident Investigation' in ICAO Regulation and in European Union Law: A Brief Overview ............................. 46

2.7 Assistance to Aircraft Accident Victims and Their Families in International and EU Law ......................................................... 48

Essential Bibliography ...................................................................... 52

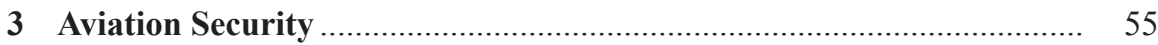

3.1 Aviation Security in the International System ................................. 55

3.2 Common EU Provisions for the Prevention of Acts of Unlawful Interference ............................................................... 59

3.3 New Rules on Civil Aviation Security in the European Union ......... 66

3.3.1 Screening Methods Applied to European Union Passengers ... 77 Essential Bibliography ...................................................................... 81

4 Primary Rights of Passengers ........................................................... 83

4.1 Air Carrier Liability in the Case of Death or Injury of Passengers.... 83

4.1.1 Compensation in the Case of Passenger Injury or Death ....... 86

4.2 Air Carrier Obligation of Insurance to Cover Possible Harm to Passengers .............................................................................. 87

4.3 The Rights of Persons with Reduced Mobility ............................... 89

Essential Bibliography ..................................................................... 97 


\section{The Protection of the Right to Privacy in the Context of}

Security and Commercial Practices ...................................................... 99

5.1 International and EU Regulations on PNRs................................. 99

5.1.1 The EU-USA Agreement on the Processing and Transfer of PNR Data by Air Carriers ................................ 104

5.1.2 The EU-Australia Agreement ........................................ 114

5.1.3 The EU-Canada Agreement............................................. 117

5.2 Advertising and the Right of the Passenger-Consumer to

Know the Final Fares and Rates of Air Carriers ............................. 122

5.2.1 Optional Price Supplements ............................................ 125

5.3 Computerized Reservation Systems (CRSs) ................................. 127

5.4 Alliances Between Air Carriers and Code-Sharing:

The Impact on the Protection of Passenger Rights.......................... 130

Essential Bibliography ..................................................................... 137

6 Secondary Rights of Passengers ........................................................... 139

6.1 Definition and Nature of 'Secondary' Rights of Passengers............ 139

6.2 The 'Charter of Passenger Rights' ................................................... 139

6.3 The Protection of the Secondary Rights of Passengers Under International Law ....................................................................... 141

6.4 Regulation (EC) No 261/2004 _.................................................... 144

6.4.1 Denied Boarding............................................................ 158

6.4.2 Long Delays of Flights..................................................... 164

6.4.3 Cancellations ................................................................. 173

6.5 Sanctions and Penalties Under Regulation (EC) No 261/2004........ 185

6.6 The Relationship Between Regulation (EC) No 261/2004
and the Montreal Convention.................................................... 190

Essential Bibliography ..................................................................... 198

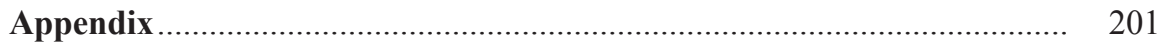

Appendix of Documentation ................................................................. 201

I. Aviation Safety .............................................................. 201

II. Aviation Security................................................................ 283

III. Primary Rights of Passengers................................................... 293

IV. The Protection of the Right to Privacy in the Context of Security and Commercial Practices .................................... 327

V. Secondary Rights of Passengers............................................. 351

Table of Cases ................................................................................. 359

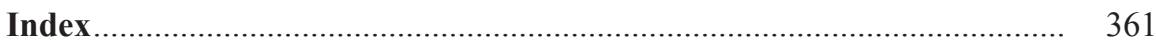




\section{List of Abbreviations}

$\begin{array}{ll}\text { API } & \text { Advance Passenger Information } \\ \text { ASM } & \text { Air Space Management } \\ \text { ATFM } & \text { Air Traffic Flow Management } \\ \text { AUC } & \text { Air Transport Users Council } \\ \text { Bull. EC } & \text { Bulletin of the European Community } \\ \text { Bull. EU } & \text { Bulletin of the European Union } \\ \text { CBSA } & \text { Canada Border Service Agency } \\ \text { CFSP } & \text { Common Foreign and Security Policy } \\ \text { CRS } & \text { Computerized Reservation Systems } \\ \text { D.l. } & \text { Decreto legge-Decree Law } \\ \text { D.lgs. } & \text { Decreto legislativo-Legislative Decree } \\ \text { D.m. } & \text { Decreto ministeriale-Ministerial Decree } \\ \text { D.p.r. } & \text { Decreto del Presidente della Repubblica-Presidential Decree } \\ \text { DHS } & \text { Department of Homeland Security } \\ \text { EASA } & \text { European Aviation Safety Agency } \\ \text { EC } & \text { European Community } \\ \text { ECAC } & \text { European Civil Aviation Conference } \\ \text { ECC } & \text { European Consumer Centres } \\ \text { ECHR } & \text { European Convention on Human Rights } \\ \text { ECR } & \text { European Court of Justice Reports } \\ \text { EDPS } & \text { European Data Protection Supervisor } \\ \text { EEC } & \text { European Economic Community } \\ \text { EESC } & \text { European Economic and Social Committee } \\ \text { ELFAA } & \text { European Low Fares Airline Association } \\ \text { ESSG-17 } & \text { European SAFA Steering Group } \\ \text { FAA } & \text { Federal Aviation Administration } \\ \text { GURI } & \text { Gazzetta Ufficiale della Repubblica italiana } \\ \text { HLCAS } & \text { High-Level Conference on Aviation Security } \\ \text { IASA } & \text { International Aviation Safety Assessment Program } \\ \text { IATA } & \text { International Air Transport Association } \\ \text { ICAO } & \text { International Civil Aviation Organisation } \\ \text { IRs. } & \text { Implementation rules } \\ & \end{array}$


ISTARS Integrated Safety Trend Analysis and Reporting System

JAA Joint Aviation Authorities

NEBs National Enforcement Bodies

OASIS Online Aircraft Safety Information System

OJEC Official Journal of the European Community

OJEU Official Journal of the European Union (replaces OJEC Official Journal of the European Community from 1 February 2003)

OSI Other supplementary information

PANS Procedures for Air Navigation Services

PCIJ Permanent Court of International Justice-Reports of Judgments

PIR Property Irregularity Report

PNR Passenger Name Record

PRMs Persons with Reduced Mobility

SAFA Safety Assessment of Foreign Aircraft

SARPS Standard and Recommended Practices

SDR Special Drawing Rights

SES I package Single European Sky I package

SSI Special Service Information

SSR Special Service Request

TEU Treaty on European Union

TFEU Treaty on the Functioning of European Union

USOAP ICAO's Universal Safety Oversight Audit Programme 